Psychology, 2015. - №58. - P. 281-342. -Режим доступу: http://onlinelibrary.wiley.com/doi/10.1111/j.1 744

4. Мойсеєнко І.П. Інформаційноаналітичне забезпечення фінансової безпеки суб'єктів господарювання / І.П. Мойсеєнко, М.Я. Демчишин // Актуа- льні проблеми економіки. - 2009. - № 10. - С. 239-245.

5. Кендюхов О. В. Організаційноекономічний механізм управління інтелектуальним капіталом підприємства. [Електронний варіант] / О. В. Кендюхов. Режим доступу : www.lib.uaru.net/diss/cont/349143.html

$$
\text { 6. Dr Marek Kunasz. (2008), }
$$

INTELLECTUAL CAPITAL - A NEW SOURCE OF COMPETITIVE ADVANTAGE, Vol. 1, No 1, http://www.economicssociology.eu/?9,en_intellectual-capital$\%$ E2\% 80\%93-a-new-source-of-competitiveadvantage

УДК 658.7(477)

\title{
ПРОБЛЕМИ ТА ПЕРСПЕКТИВИ РОЗВИТКУ СИСТЕМИ МАТЕРІАЛЬНО-ТЕХНІЧНОГО ЗАБЕЗПЕЧЕННЯ ПІДПРИЄМСТВ В УКРӒ̈̈Н
}

\author{
Маслова В.О., к.е.н., доцент, \\ Лисиця М.О., магістр (УкрДУЗТ)
}

У статті розглянуто тенденції розвитку системи матеріально-технічного забезпечення та збуту продукиії підприємств в Україні, побудованої на базі використання конкурентних методів, зокрема електроних закупівель. Відзначено, щуо реалізачія положень чинного законодавства у цій сфері дозволяє реформувати украӥнську систему державних закупівель в більи прозору, ефективну і привабливу для участі. Запропоновано удосконалити систему електроних закупівель за рахунок залучення комериійного сектору економіки та створення міждержавної платформи електроних торгів.

Ключові слова: матеріально-технічне забезпечення підприємства, система державних закупівель, електронні торги.

\section{ПРОБЛЕМЫ И ПЕРСПЕКТИВЫ РАЗВИТИЯ СИСТЕМЫ МАТЕРИАЛЬНО-ТЕХНИЧЕСКОГО ОБЕСПЕЧЕНИЯ ПРЕДПРИЯТИЙ В УКРАИНЕ}

\author{
Маслова В.А., к.э.н., доцент, \\ Лисица М.О., магистр (УкрГУЖТ)
}

В статье рассмотрено тенденции развития системы материально-технического обеспечения и сбыта продукиии в Украине, построенной на базе использования конкурентных методов, в частности электронных закупок. Отмечено, что реализация положений действующего законодательства в этой сфере позволяет реформировать

(с) Маслова В.O., Лисиця М.О.
Вісник економіки транспорту і промисловості № 60, 2017 
украинскую систему государственных закупок в более прозрачную, эффрективную $и$ привлекательную для участия. Предложено усовершенствовать систему электронных закупок за счет привлечения коммерческого сектора экономики и создания межгосударственной платформы электронных торгов.

Ключевые слова: материально-техническое обеспечение предприятия, система государственных закупок, электронные торги.

\title{
PROBLEMS AND THE PROSPECTS OF DEVELOPMENT OF SYSTEM OF MATERIAL SUPPORT OF THE ENTERPRISES IN UKRAINE
}

\author{
Maslova V.O., PhD Econ., associate professor, \\ Lisitsa M.O., master (UkrSURT)
}

In article it is considered tendencies of development of system of material support and sales of products in Ukraine constructed on the basis of use of competitive methods, in particular electronic procurement. It is noted that implementation of provisions of the current legislation in this sphere allows to reform the Ukrainian system of government procurement in more transparent, effective and attractive to participation due to introduction of electronic procurement, a possibility of involvement of professional procurement specialists for tendering process, creation of the centralized purchasing organizations. Among shortcomings of the existing system of purchases the lack of access of the commercial organizations as customers to the system of electronic procurement and the conditional nature of interstate electronic procurement is noted. It is offered to improve the system of electronic procurement due to attraction of the commercial sector of economy and creation of the interstate platform of the electronic auction.

Key words: material support of the enterprise, system of government procurement, electronic auction.

\section{Постановка}

Стратегічний розвиток підприємства пов'язаний 3 можливітю вирішення таких питань, як здешевлення виготовлення продукції при одночасному збереженні або підвищенні рівня ії якості, а також отримання доступу до існуючих та потенційних ринків збуту цієї продукції. Розвиток інформаційних технологій, транспортного забезпечення та інтеграційних процесів в Україні відкривають нові можливості для вітчизняних підприємств в оптимізації власних систем матеріально-технічного забезпечення виробництва та збуту продукції. Мова йде, перш за все, про створення та розвиток так званих інформаційних та транспортно-логістичних центрів у якості централізованих закупівельних організацій, а також системи електронних закупівель, що передбачає використання конкурентних методів. Тобто підприємство отримує необхідну продукцію належної якості за конкурентними цінами. Це дозволяє за різними оцінками бізнес-консультантів отримувати значне скорочення операційних витрат, загальної вартості матеріалів, що закуповуються, та в цілому підвищити ефективність діяльності. Саме тому проблеми подальшого удосконалення систем матеріально-технічного забезпечення та збуту продукції, як централізованого, так й децентралізованого, є актуальними для підприємств та економіки України в цілому, вирішення яких дозволить підвищити їх конкурентоспроможність на національному та світовому ринках.

Аналіз останніх досліджень i

Вісник економіки транспорту і промисловості № 60, 2017 
публікацій показав, що питанням оптимізації матеріально-технічного забезпечення у різних галузях та економіки України в цілому приділяється велика увага як науковців, так і фахівців. Серед досліджень за останні роки можна виділити праці Диканя В.Л. [3,4], Полякової О.М., Шраменко О.В. [5], Устенко М.О. [6] та інших вчених, присвячені проблемам логістичного управління матеріальнотехнічним забезпеченням підприємств та розвитку транспортно-логістичної інфраструктури в Україні. Питання застосування конкурентних методів в організації матеріально-технічного забезпечення, зокрема впровадження системи електронних закупівель в державному та комерційному секторах економіки досліджувалися у працях таких вчених та практикуючих фахівців, як Вареник В.М., Свчин Л.О. [7], Слагін Ю.В. [8], Шатковський О. [9], Чабан В. [10], Блашук O [11] Чимало праць в електронних ресурсах присвячено аналізу існуючої законодавчої бази 3 наведених питань, зокрема Закону України «Про здійснення державних закупівель» № 1197VII від 10.04.2014 р. та Закону України «Про публічні закупівлі» № 922-VIII від 5.12.2015 p.

Виділення невирішених частин загальної проблеми. У той же час у більшості зазначених робот, особливо в сфері організації матеріально-технічного забезпечення за допомогою використання конкурентних методів, зокрема електронних закупівель, питання удосконалення стосуються переважно державного сектору економіки та в межах України. Це суттєво звужує можливості вітчизняних підприємств щодо можливості підвищення ефективності діяльності та збільшення обсягів виробництва та збуту продукції. Тому виникає необхідність подальшого аналізу проблем та перспектив розвитку системи матеріально-технічного забезпечення підприємств на основі використання конкурентних методів не тільки у державному, але й комерційному секторі економіки України, як на національному, так i міжнародному ринках.

Таким чином, метою статті $\epsilon$ визначення існуючих проблем та формування пропозицій щодо перспектив розвитку системи матеріально-технічного забезпечення та збуту продукції підприємств в Україні, побудованої на базі використання конкурентних методів, зокрема електроних закупівель, в умовах зростання динаміки змін як економікополітичної ситуації в країні та світі, так i постійних змін зв'язків між покупцями та постачальниками.

Виклад основного матеріалу. Питання удосконалення організації системи матеріально-технічного забезпечення, особливо в державному секторі, в Україні вже досить тривалий час знаходится у порядку деному законодавчої влади. Пов'язано це, по-перше, 3 тим, що держзакупівлі займають левову частку в ВВП України (близько 18\%); по-друге, і 3 низькою ефективністю діючої системи (закупівлі за завищеними цінами внаслідок недостатньої конкуренції, складна процедура підготовки та подання тендерних пропозицій); по-третє, у зв'язку 3 укладанням між Україною і ЄС Угоди про асоціацію, а також приєднання України до Угоди про державні закупівлі СОТ, виникає необхідність адаптації відповідного законодавства до правил ЄС. Останні, найзначніші, зміни закріплені в прийнятому наприкінці 2015 року Законі України «Про публічні закупівлі» [2].

Аналіз змін у законодавстві щодо державних закупівель показав, що в основу проведення публічних закупівель за новим Законом [2] закладені ті ж принципи, що і в старому законодавстві [1]. Ці принципи цілком відповідають кращим світовим практикам: добросовісна конкуренція серед учасників; максимальна економія та ефективність; відкритість і прозорість на всіх стадіях закупівель; недискримінація 
учасників; об'єктивна і неупереджена оцінка тендерних пропозицій; запобігання корупційним діям і зловживанням. Проте, механізми реалізації цих принципів в новому Законі змінилися.

Тотальне застосування електронних закупівель, яке введено Законом, стало найвагомішим нововведенням $\mathrm{y}$ сфері державних закупівель. Починаючи 31 квітня 2016 року всі органи виконавчої влади та замовники, які здійснюють діяльність в окремих сферах господарювання, а 31 серпня 2016 року i всі інші замовники повинні здійснювати державні закупівлі, які потрапляють під сферу дії Закону, 3 використанням електронної системи закупівель. Застосування електронної системи за бажанням замовників можливо також і для закупівель, які не регулюються цим Законом.

Таким чином, процедури закупівель, включаючи створення, розміщення, оприлюднення та обмін інформацією i документами (в тому числі подача тендерних пропозицій, їх розкриття i оцінка), проводяться в електронній системі.

Серед загальних вимог до електронної системи закупівель загальнодоступність, забезпечення недискримінації та рівних прав в процесі роботи в системі всіх зацікавлених осіб, рівного доступу до інформації, іiі збереження і конфіденційність.

Підхід до визначення замовників також не змінився. Це переважно органи державної влади, місцевого самоврядування та соціального страхування. Одним 3 найважливіших критеріїв віднесення до замовників $\epsilon$ забезпечення потреб держави або територіальної громади.

Крім того, скоротилася кількість дозволених процедур закупівель. Законом дозволяється використання тільки трьох процедур: відкриті торги, конкурентний діалог і переговорна процедура. Основною процедурою залишаються відкриті торги,

для яких обов'язковим $є$ проведення електронного аукціону, спрямованого на зниження ціни закупівлі. Конкурентний діалог замовники можуть застосовувати, якщо визначити необхідні технічні, якісні характеристики (специфікації) робіт або вид послуг без проведення переговорів неможливо, а предметом закупівлі $\epsilon$ консультаційні, юридичні послуги, розробка інформаційних систем, програмних продуктів, здійснення наукових досліджень, експериментів або розробок, виконання дослідноконструкторських, будівельних робіт. Переговорна процедура застосовується тільки в суворо визначених Законом випадках за конкурентними принципами, що дозволяє проводити переговори 3 кількома учасниками.

Також передбачено суттєві зміни в організації державних закупівель, а саме: можливість проведення закупівель не тільки тендерним комітетом, а й уповноваженою особою (особами), призначеними замовником. Однією 3 важливих проблем старої системи закупівель в Україні аналітики називають відсутність кваліфікованих фахівців із закупівель, оскільки до тендерного комітету мали входити виключно співробіт.ники замовника, для яких участь у тендерному комітеті найчастіше $\epsilon$ додатковим навантаженням до основних обов'язків і які не володіють необхідними знаннями в сфері закупівель [9, 10]. Можливість залучення третіх осіб, якщо такими особами будуть професійні закупівельники, повинна вирішити цю проблему i підвищити ефективність системи матеріально-технічного забезпечення підприємств та організацій [4, $5]$.

3 цього приводу у частині
організації закупівель
нововведенням стало надливим
проводити закупівлі через так звані
централізовані закупівельні організації.
Такі організації будуть наділені правами і

Вісник економіки транспорту і промисловості № 60, 2017 
обов'язками замовника i, відповідно, можуть проводити закупівлі i укладати угоди в інтересах замовників. Світовий досвід застосування такого підходу до організації державних закупівель показав значну економію ресурсів в процесі здійснення закупівельної діяльності, а отже, i більшу ефективності цих закупівель.

Узагальнюючи вищенаведене, можна відзначити, що особливістю даного етапу розвитку вітчизняної системи матеріально-технічного забезпечення $\epsilon$ впровадження електронних процедур закупівель на законодавчому рівні. Використання в діяльності підприємств та організацій електронних форм торгівлі не тільки забезпечить прозорість торговозакупівельних операцій, але i дозволить отримувати відчутний економічний ефект у вигляді підвищення рентабельності, скорочення виробничих i транзакційних витрат.

Втім, не зважаючи на суттєві переваги існуючої на даний момент системи матеріально-технічного забезпечення, в процесі дослідження були визначені певні недоліки, серед яких основними можна виділити наступні.

$$
1 \text { Відсутня можливість }
$$

використання комерційними структурами «пулу» постачальників, який створюється при проведенні державних закупівель, 3 метою підвищення їхньої ефективності діяльності. Так, єдиною автоматизованою системою електронних торгів в Україні $\epsilon$ «ProZorro», що включає значну кількість електроних торгівельних майданчиків (кількість постійно змінюється) [9]. Слід зазначити, що система електронних торгів «ProZorro», на разі, передбачена лише для державного сектору економіки України [8]. Наприкінці 2016 року майданчикиучасники державних закупівель «ProZorro» об'єдналися та створили в Україні недержавну електронну систему «Rialto», що побудована за аналогічними принципами системи державних закупівель, але не є іiі сладовою частиною [11].

2 Проведення міжнародних торгів, що відкриває додаткові переваги для вітчизняних замовників та постачальників, є умовністю, через відсутність зв'язку між майданчиками різних країн. Зокрема, експортно-орієнтована економіка Білорусі при наявності відповідної інформаційноаналітичної платформи видкриває додаткові можливості щодо збуту продукції українського бізнесу. У створенні такої єдиної міждержавної платформи зацікавлені й колишні партнери України по СНД - Росія та Казахстан.

На основі виявлених недоліків можна визначити й пропозиції щодо подальшого удосконалення організації системи матеріально-технічного забезпечення та системи збуту підприємств України, а саме створення (на першому етапі реалізації проекту - для Білорусії, України, Росії та Казахстану, з подальшим розширенням на інші країни (в першу чергу - Індія, Китай, Польща і Арабатська Емірати (першочергово в аграрному секторі))) єдиної інформаційно-аналітичної платформи, яка складається 3 двох сегментів (майданчиків):

$$
\text { - «державний майданчик» }
$$

формується шляхом копіювання i необхідного структурування інформації 3 усіх державних майданчиків (різних країн). Реалізація переходу на майданчик-джерело (інформаціï) 3 даної платформи, 3 метою подачі пропозиції;

- «комерційна майданчик»

формується шляхом копіювання i необхідного структурування інформації 3 усіх комерційних майданчиків (різних країн), за їх наявністю. Реалізація подачі і прийому пропозицій на даному майданчику (даної платформи), а також реалізація переходу на майданчик-джерело (інформації) 3 даної платформи, 3 метою подачі пропозиції.

Надалі можливо доповнення третім сегментом - це «дошка оголошень» або 
«персональний майданчик» - формується шляхом копіювання i необхідного структурування інформації з усіх дощок оголошень різних країн.

Тобто, метою даного проекту $\epsilon$ створення платформи для зручного та ефективного використання єдиного, незалежного від суб'єкта економічної діяльності (В2B, Р2P, В2Р, Р2В ..., де В юридична особа, бізнес; $\mathrm{P}$ - фізична особа, персона, 2 - «tо», напрямок взаємодії) HUBa (у переносному сенсі: сховища інформації, що надходить 3 різних місць), в якому акумулюється інформація для всіх сегментів ринку (економіки) в розрізі країн про проведення закупівель/продажів державного, комерційного або персонального характеру.

Подальший розвиток системи матеріально-технічного забезпечення та збуту у запропонованому напрямку дозволить не тільки підвищити економічну ефективність діяльності замовників та збільшити обсяги продажів постачальників, але й забезпечити зростання та конкурентоспроможність економіки України.

Висновок. Таким чином, реалізація положень, закладених у Законі України «Про публічні закупівлі» [2] дозволяє реформувати українську систему державних закупівель в більш прозору, ефективну і привабливу для участі. Це і впровадження електронних закупівель, i можливість залучення професійних фахівців із закупівель для проведення тендерів, і створення централізованих закупівельних організацій. Подальше удосконалення організації системи матеріально-технічного забезпечення та системи збуту за рахунок створення міждержавної платформи електроних торгів та залучення до електронних торгів суб'єктів господарювання комерційного сектору дозволить забезпечити зростання та конкурентоспроможність економіки України.

\section{ПЕРЕЛІК ВИКОРИСТАНИХ ДЖЕРЕЛ}

1 Про здійснення державних закупівель [Текст]: закон України: офіц. текст: від 10.04.2014 № 1197-VII // Відомості Верховної Ради (ВВР). - 2014. № 24. - ст.883.

2 Про публічні закупівлі [Текст]: закон України: офіц. текст: від 5.12.2015p. № 922-VIII // Відомості Верховної Ради (ВВP). - 2016. - № 9. - ст.89.

3 Дикань, В.Л. Основи логістичної інтеграції при формуванні логістичних систем через утворення територіальнопромислового кластера [Текст] / В.Л.Дикань // Міжнародний технікоекономічний журнал «Українські залізниці». - 2014. -№9(15). - С.23-26.

4 Дикань, В.Л. Логістичне управління матеріально-технічним забезпеченням підприємств залізничного транспорту [Текст] / В.Л.Дикань // Вісник економіки транспорту і промисловості. 2014. - № 45. - C. 51-54

5 Полякова, О.М. Сучасні тенденції розвитку транспортно-логістичної інфраструктури в Україні і світі [Текст] / О.М. Полякова, О.В. Шраменко // Вісник економіки транспорту і промисловості. 2017. - № 58. - С. 126-134.

6 Устенко, М. О. Актуальність формування транспортно-логістичних систем в умовах євроінтеграції [Текст] / М. О. Устенко // Вісник економіки транспорту і промисловості - 2015. - № 49. - С. 207210.

7 Вареник, В.М. Особливості застосування системи державних закупівель ProZorro (Прозоро) [Текст] / В.М. Вареник, Л.О. Євчин // Свропейський вектор економічного розвитку. - 2016. - № 2 (21). - С. 6-15.

8 Єлагін, Ю.В. Публічні закупівлі підприємств залізничного транспорту України в умовах реформування [Текст] / Ю.В. Слагін, Г.В. Коршикова // Вісник економіки транспорту і промисловості. 2017. - № 59. - C. 62-68.

Вісник економіки транспорту і промисловості № 60, 2017 
9 Шатковський O. Електронні [Текст] / В. Чабан.// Юридична Газета. - 22 державні закупівлі: пошук українського грудня 2015p. - №52(498). - С.22-23.

шляху [Електронний ресурс] / O. 11 Блащук, О. В Украине запустили Шатковський, Г. Файвеш. - Режим Rialto - открытую систему закупок для доступу: http://eupublicprocurement.org. бизнеса по принципам ProZorro ua/e-procurement-finding-a-way-for-ukraine. [Електронний ресурс] / О. Блащук. - Режим html?lang=RU

10 Чабан, В. Електронні державні закупівлі: на шляху до інтеграції з $\mathrm{CC}$ доступу: https://ain.ua/2016/10/21/v-ukrainezapustili-rialto-otkrytuyu-sistemu-zakupokdlya-biznesa-po-principam-prozorro

\title{
УДК 339.166.5:656.2
}

\section{ТЕОРЕТИЧНІ АСПЕКТИ ФОРМУВАННЯ ТА ВИКОРИСТАННЯ ІНТЕЛЕКТУАЛЬНОГО ПОТЕНЦАЛУ ПІДПРИЕМСТВ ЗАЛІЗНИЧНОГО ТРАНСПОРТУ}

\author{
Обруч Г.В., к.е.н., ст. викладач, \\ Смцова В.Е., магістр (УкрДУЗТ)
}

У статті розглянуто важливість людського розвитку для забезпечення сталого зростання країни. Визначено, що в умовах постіндустріального суспільства та поширення економіки знань конщепџія людського розвитку цे використання інтелектуальних ресурсів набуває особливої актуальності для забезпечення економічного зростання суб'єктів господарювання та базису формування їх конкурентних переваг. Досліджено сутність поняття інтелектуального потениіалу підприємств та визначено основні його складові. Сформовано комплекс мотиваційних заходів розвитку інтелектуального потенціалу підприємств залізничного транспорту.

Ключові слова: цілі сталого розвитку, людський розвиток, інтелектуальний потенціал, комплекс мотиваційних заходів, підприємства залізничного транспорту.

\section{ТЕОРЕТИЧЕСКИЕ АСПЕКТЫ ФОРМИРОВАНИЯ И ИСПОЛЬЗОВАНИЯ ИНТЕЛЛЕКТУАЛЬНОГО ПОТЕНЦИАЛА ПРЕДПРИЯТИЙ ЖЕЛЕЗНОДОРОЖНОГО ТРАНСПОРТА}

\author{
Обруч А.В., к.э.н., ст. преподаватель, \\ Емцова В.Э., магистр (УкрГУЖТ)
}

В статье рассмотрена важность человеческого развития для обеспечения устойчивого роста страньл. Определено, что в условиях постиндустриального общества и распространения экономики знаний концепция человеческого развития и использования интеллектуальных ресурсов приобретает особую актуальность для обеспечения экономического роста субъектов хозяйствования и базиса формирования их конкурентных преимуществ. Исследована сущчость понятия интеллектуального потенциала предприятий и определень основные его составляющие. Сформирован

(C) Обруч A.B., Смцова В.Е.
Вісник економіки транспорту і промисловості № 60, 2017 